\title{
Eva Miller*
}

\section{Crime and Testament: Enemy Direct Speech in Inscriptions of Esarhaddon and Ashurbanipal}

\author{
https://doi.org/10.1515/janeh-2018-0015
}

\begin{abstract}
Neo-Assyrian royal inscriptions are always narrated in the firstperson voice of the king. Within this framing narrative, the device that we would call 'direct speech' is used only rarely, and judiciously. The texts that make the greatest use of this literary device both come from a period of particular innovation and experimentation in royal text forms: Esarhaddon's Nineveh A and Ashurbanipal's narratives about his campaign against Elamite king Teumman. In these examples, and in other texts of the time including Esarhaddon's Succession Treaty, the words of enemies stand out as particularly threatening - and yet also particularly useful, as a literary device employed to further Assyrian agendas. Royal narratives use enemy speech for one of two purposes: either to document criminality, or to show enemies, in defeat and despair, testifying to the might and rightness of their Assyrian conquerors. Looking at all examples of speech - from enemies, gods, and the Assyrian king - I distinguish between 'direct speech' (as a literary device) and 'quotation' (as a practice). Most, though not all, direct speech in the sources considered here is also quotation, in that it seeks to document and preserve speech made in some other prior form (a verbal statement, a letter, an omen on an animal's liver). Quotations demonstrate royal legitimacy and enemy culpability, while literary invention allows enemy voices to be turned to new purposes, as forced testament to Assyrian supremacy.
\end{abstract}

Keywords: Neo-Assyrian period, royal inscriptions, enemies, kingship

Neo-Assyrian royal inscriptions, though composed by elite scribes at the royal court, are, with only rare exceptions, always given in the first-person voice of the

*Corresponding author: Eva Miller, History Department, University College London, London WC1E 6BT, United Kingdom of Great Britain and Northern Ireland, E-mail: e.miller@ucl.ac.uk 
king. ${ }^{1}$ He is the protagonist of his own narrative and the authoritative narrative voice who interprets his own successes. Chief among the successes that must be documented in royal inscriptions is the king's triumph over enemies and his expansion of Assyrian power - all done at the will of and in pious submission to the Assyrian gods. But on rare occasions, the first-person narrative voice of the king makes way for another voice - including intriguingly, sometimes the voices of those defeated or soon-to-be-defeated enemies of Assyria.

In Assyrian annals, the narrative device that we would call 'direct speech' is employed very rarely throughout most of Assyrian history (beyond the framing device of the entire text as royal speech), with an uptick in its popularity in the royal inscriptions of the last two well-attested Neo-Assyrian monarchs, Esarhaddon and Ashurbanipal (Gerardi 1989: 245-46). Although Esarhaddon and Ashurbanipal employ this literary feature more often than their predecessors, it is still used only sparingly and judiciously. Furthermore, it is usually used only in unusual circumstances and generally for a very specific reason.

The narrative superstructure of all royal inscriptions, with the king as firstperson narrator, makes manifest the broader way in which any examples of 'enemy speech' are of course mediated through an Assyrian royal perspective. It is always an Assyrian voice speaking through an enemy puppet (created by an Assyrian stylus for Assyrian purposes). Thus the subordination of the enemy's voice to that of the Assyrian king at a narrative level is paralleled at an ideological level; the enemy's voice is to be understood and valued only in the context of a support for an Assyrian viewpoint and a justification of Assyrian actions. As well as rendering speech directly, Esarhaddon and Ashurbanipal's texts often talk about enemy speech, usually because of the dangerous criminality and potency of enemy voices. This article will look at how direct speech is used in several significant written and visual narrative sequences: Esarhaddon's Nineveh A, and various sources narrating Ashurbanipal's defeat of Elamite king Teumman. I have chosen these sources because they are simultaneously

1 It is usual for the king to use the first-person for actions carried out by the army or by magnates leading campaigns at his command, but there are instances where the narrative breaks into a third-person account of a magnates' actions. See for instance an inscription of Shalmaneser IV (RIMA 3 A.0.105.1: 4-13) in which a campaign led by his magnate Šamšì-ilu is reported in third-person - although the reception of tribute at the end of it is reported in firstperson, presumably back in the voice of the king to whom, of course, ultimately go the spoils. These third-person interludes are implicitly still in the voice of the king, who serves as overall narrator, reporting on his magnates' or his army's activities. Elsewhere narratives sometimes feature a third-person voice for reasons that are less clear; see Grayson (1980a: 165-67) for a discussion of narratives that shift between first and third person and their potential significance for understanding composition processes. 
exemplary and unusual Neo-Assyrian royal texts; they represent the innovation, creativity, and flexibility of royal texts during the reigns of these two late Assyrian monarchs. They show us Esarhaddon and Ashurbanipal, in different contexts, trying to understand how best to turn that treacherous figure, 'the enemy', to their literary and ideological advantage. Enemy speech in these texts appears alongside other direct speech, usually by the king or the gods, whose own words confirm the Assyrian king's legitimacy and the enemies' criminality.

I will show that enemy direct speech in these examples serves one of two purposes: either to document speech crimes 'in their own words', or to use enemy voices to testify to the glory of the Assyrian king and the foolishness of going out against him. In this latter role, enemy voices can become powerful tools of legitimation for an Assyrian monarch.

\section{Direct speech and quotation}

Before we examine speech in Assyrian narratives, we should consider what 'direct speech' is, how we recognise it in Akkadian, what makes it stand out within a royal narrative, and how I will distinguish a subcategory of 'quotations'. The term 'direct speech' is borrowed from narratology and is employed here because of its familiarity to English speakers. However, it should be noted that our distinctions between 'direct' and 'reported' speech are not always as clear in Akkadian (either grammatically or conceptually). Nonetheless, as this article will show, there is a specific and distinctive device equivalent to our idea of direct speech - a device which we will see is used in consistent ways and for consistent purposes.

In narratology, direct speech is usually related to a mimetic narrative style, in contrast to diegetic styles. These terms derive from a distinction proposed by Socrates in Plato's Republic (Book III) between speech in which the poet creates an illusion that his words are someone else's (mimesis) and speech in the undisguised voice of the poet himself (diegesis). Mimesis as defined in this context then applies exactly to the narrow cases that I am interested in here: moments when the narrative breaks into 'someone else's', i. e. not the narrator's, voice. However, the diegetic/mimetic distinction in literary criticism has subsequently been used in criticism to refer not strictly to representation of speech or speakers, but to the overall question of how narratives imitate reality. These two modes are also often equated in Anglo-American narratology with 'showing' versus 'telling', a distinction usually credited to Henry James, who privileged the former. James's alleged preference for 'showing' was taken as doctrine in early 
twentieth century literary criticism and still haunts popular writing advice, though in fact his views on this narratological distinction were much more nuanced. Discussing 'dialogue' and 'description', James himself bemoaned that: 'People often talk of these things as if they had a kind of internecine distinctness, instead of melting into each other at every breath and being intimately associated parts of one general effort of expression' (James 1888: 391). Narratological criticism has since swung back and forth on the relative merits of the two modes. Most scholarship now recognises that neither is inherently superior as a narrative device, and different types of mimesis or diegesis each have their own purposes (see Rimmon-Kenan 2002: 107-109). Although the definition of mimesis in literature has been broadened beyond the Classical concern for the representation of speech, direct speech has maintained a unique importance in literary criticism. It has often been considered the purest form of mimesis, since language can only ever be mimetic of language, as Genette would have it (1983: 164). As we will see in the rest of this article, in the Assyrian context 'language' includes not just the written word, but also ominous signs.

Although narratological terms are useful in identifying what is significant about direct speech as a narrative device, the various distinctions and value judgements inherent in these traditions of narrative criticism are not always helpful when it comes to Akkadian narratives. Diegetic narration is certainly the preferred style for Assyrian annals, and it is easy to see why: the voice of the king 'telling' what happened, sometimes with vivid description, but always the master of the narrative is a powerful act of royal control. As a report of the king to the gods, it is also his duty to speak in his own voice about how he has carried out their mandate to conquer and subdue the world (a duty to report, of course, actually fulfilled by royal scribes working under him, inhabiting his royal voice). The clear preference for this royal narrative voice as the best means of communicating royal achievements, and the relative unusualness of direct speech in royal inscriptions suggests that it was not considered an important or necessary part of narration in this genre. ${ }^{2}$ This means that when it does appear there is usually a special reason why speech is being preserved 'directly'; it is not a case of an established literary preference for the device.

Orthographic conventions to mark direct speech do not exist in Akkadian: there are no inverted commas or their cuneiform equivalent. If we want to determine whether a specific section of a text is intended as speech in the voice of a figure other than the narrator, we must rely on certain vocabulary

2 In letters, in contrast, direct speech and quotation, from life and of previous written communication is the primary mode of conveying information. 
markers: verbs that indicate speech is about to begin or, most reliably, umma, 'thus', which indicates most certainly that a direct quotation will follow. However, Akkadian narrative does not always employ these introductory signals (two examples of direct speech in Nineveh A must be deduced from context, as can be seen in Table 1 below). Then we must look for other contextual clues. Most reliable is a change in pronouns or person applied to verbs, ${ }^{3}$ or a change in style (again, see Table 1 for examples). Although the first person is used in the narrative as a matter of course by the king-as-narrator, if a first-person pronoun is applied in a way that does not make sense for the king-as-narrator to be using it, we can tell that direct speech is being used. Second-person in either verbs or pronouns suggests direct speech: a 'character' speaking to another 'character' within the royal narrative.

While Esarhaddon and Ashurbanipal employ the device of direct speech more frequently than their predecessors, it still constitutes a small part of even their most speech-filled royal texts. ${ }^{4}$ When it is used, it usually preserves a significant, powerful pronouncement. For instance, prayers of Esarhaddon and Ashurbanipal and the responses to them appear in the narratives examined here. Sennacherib's announcement that Esarhaddon should succeed him as king is rendered in direct speech: Sennacherib speaks, '(saying) thus: "this is the son who is my successor"' (umma annû māru ridûtiya; RINAP 41 i 12). ${ }^{5}$ It is clear that the preservation of these as direct speech is important: these are powerful words, many of them performative, or at least legally binding (i. e. by saying that Esarhaddon will succeed him Sennacherib makes this true).

These instances of direct speech are then 'quotations' in a proper sense; they probably relied on incorporating words from other sources, trying to preserve words in their exact essence ('he will succeed me' from Sennacherib about Esarhaddon; 'I will not rest until I have dined in the midst of Nineveh', an impious boast of Ashurbanipal's enemy Teumman SAA 3 (Livingstone 1989) 31, discussed further below). I define 'quotation' as an instance of direct speech that is intended to preserve and recreate some previous instance of speech. In the examples considered here, this might mean that a text 'quotes' the written word, that it 'quotes' a remembered spoken word, or that it 'quotes' a sacrificial liver.

3 It should be noted that it is not always possible to distinguish a first from a third person in many Akkadian verb forms.

4 The only exception might be Esarhaddon's highly unusual 'Letter to the God' (RINAP 4 33) in which direct speech, quoted from royal letters, is co-equal with the first-person narratorEsarhaddon as narrative authority.

5 For all quotations from RINAP volumes, I have followed the RINAP editions and normalisation conventions. Unless otherwise noted, the translations given here are my own. 


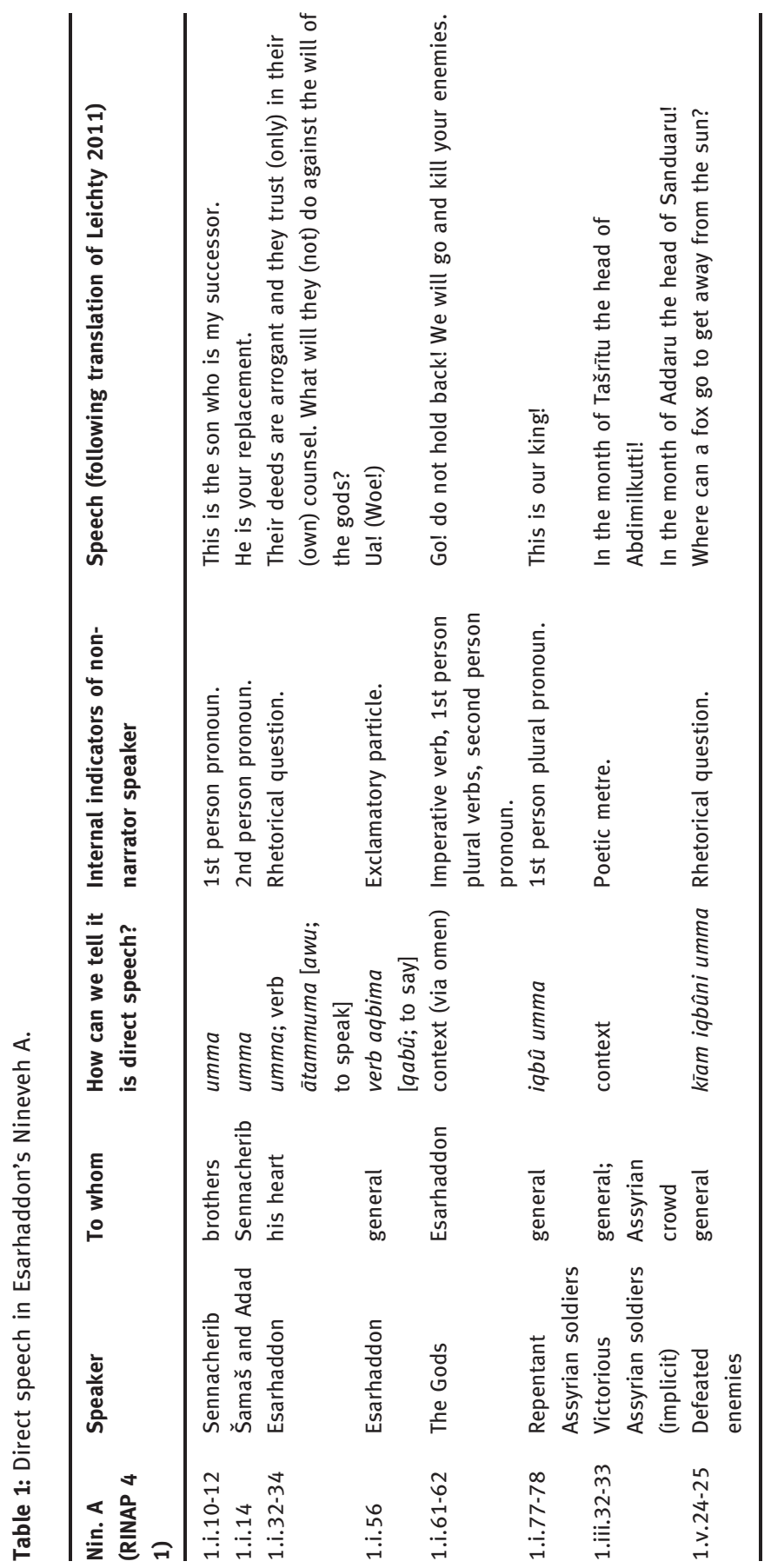


Such instances go beyond a literary device; they are understood as having a reference outside of the text and are intended to preserve speech that existed previously elsewhere. $^{6}$

I would argue that the majority of instances of direct speech in royal inscriptions are quotations of this type, though of varying degrees of mimetic faithfulness to their source. What constitutes 'mimesis', and what makes a quotation true, accurate, powerful, or documentary is culturally contingent. Some of the 'quotations' that I will identify here involve layers of interpretation - for instance, because the quoted speech was received through oracular signs that require professional 'translation' into a message delivered in Akkadian speech. Yet for the authors of these texts, Akkadian narrative might still be a true and accurate 'quotation' of unclear images received in a dream.

Even where the antecedent of a quotation is human speech, it might be at a layer of remove that would make it difficult to render exactly. It is unlikely that we could ever prove, or that Ashurbanipal could ever prove, that Teumman said exactly what he was claimed to have said in the assembly of his troops, even if his words had been preserved in contemporaneous letters at the time. But I would suggest that in a meaningful sense, the Assyrian understanding of quotation as powerfully preservative, as language mimetic of language in Genette's terms, is not very different from our own understanding of quotation. The report of what Teumman said is intended to preserve his own, real words, in their essence and intent. ${ }^{7}$ Those words were important to document, since they justify his uniquely harsh treatment in Ashurbanipal's narratives. ${ }^{8}$ These texts

6 As Baruchi-Unna $(2013,2017)$ has demonstrated, the inclusion of certain types of quotations in royal inscriptions can also tell us something about the process by which royal inscriptions were composed; looking at a prayer that appears in Ashurbanipal's $\mathrm{L}^{4}$, he suggests that it is likely that the prayer, as composed beforehand was incorporated directly into the longer text with the scribe looking at multiple texts from which to construct his narrative (Baruchi-Unna 2013: 612-19). This may have been the case also with legally or ritually important words that appear in Nineveh A and Ashurbanipal's Teumman narratives, although they may be quoted from memory - less accurate but nonetheless with reference to a prior speech instance.

7 In this instance, there could also be an intermediate stage of quotation, in which a correspondent from Elam preserved these words in a letter, in Akkadian cuneiform. As well as the letters that were being exchanged directly between Ashurbanipal and Teumman via Teumman's messengers, as discussed in the royal inscriptions, Ashurbanipal might also have been receiving reports from informants within Elam. Correspondents are often motivated to report information to the king. See Radner 2015 on royal correspondence and SAA 21 (Parpola 2018) 58-74, 115-123 for letters to and from Elam in Ashurbanipal's correspondence.

8 Teumman's boastful words are also arguably indexed in his punishment: see Gilibert 2018, who argues that the famous 'Garden Party' relief of Ashurbanipal responds to this very boast. This is discussed further below. 
consider preservation and documentation of such important words as part of their mission, equivalent to recording or capturing on film in a modern context. Within texts about royal legitimacy and enemy punishment, they document and justify royal actions.

We also see that there is an emphasis on the speech, especially treacherous enemy speech, within narratives, even where that speech is not directly quoted. This is particularly evident in Ashurbanipal's accounts, where forced readings and possible forced testimonies are included in the reports of Ashurbanipal's victory processions and triumphs on the battlefield (discussed below). We see this emphasis also in Esarhaddon's Succession Treaty, created shortly after Nineveh A, in which treacherous speech and thought must be preserved and reported. Ultimately, enemy speech is uniquely potent. As mentioned already, this potency can be turned towards Assyrian ends, when enemies in defeat and despair testify to the might of their conquerors.

\section{The significance of enemies to imperial identity}

How should kings who proclaim their divine-given right to rule and expand their territory (Machinist 1993: 86) handle the existence of individuals who oppose that right? On the one hand, enemies play a vital role in allowing a king to be a king: without them, he would have no one to expand against and no one to conquer (a vital duty of Assyrian kingship as the Sargonids understood it). On the other hand, enemies also can call into question both the rightness of his mission (what if the gods have raised them as instrument against him?) and the rightness of that particular king for kingship (should he fail to subdue them speedily and easily, is he really the king the gods want?).

Enemies are then the paradox at the heart of royal discourses in much of the Near East. This is especially true in Neo-Assyrian texts and art, where warfare and the punishment of enemies is even more important than it is to other Near Eastern kings. Enemies must be centred in Neo-Assyrian royal texts and art so that their subjugation and defeat can be recreated. But the centring must not elevate them to the status of real threat, since victory by a legitimate Assyrian king is divinely ordained from the beginning. The question of royal legitimacy is at the heart of Nineveh $\mathrm{A}$, as Esarhaddon explains his own right to the royal throne in the wake of a conflict with his brothers that ended, unsatisfactorily, in their escape. In this less than ideal circumstance, Esarhaddon marshalled various supporting documentation in the form of direct speech from all quarters to prove his legitimacy - including ultimately, as we shall see, from his enemies. 
Feldman argues that a distinctive Assyrian visual style allowed representations of the foreign other that both preserved their alterity and yet expressed Assyrian control over them by stylistically assimilating and Assyrianising enemies and their material objects. She explains that 'the other must be present in order to keep alive the memory of its own conquest' (Feldman 2014: 92). By rendering that other into something Assyrian 'in style, if not in "content", (Feldman 2014: 108), the dangerous potency of foreign ideas and values was neutered and the mastery of Assyria over the Other demonstrated. Feldman's analysis deals specifically with the representation of foreign objects, but it is illuminating for the process of Assyrian representation more generally. Time, space, people, and historical events were all Assyrianised through their representation in Assyrian narratives. Putting speech into the mouth of enemies as characters in texts and visual narratives was a part of this process whereby an enemy threat, challenge, or crime was recorded - but only on Assyrian terms.

Foreigners and enemies are closely related categories, often interchangeable. Assyrians can ally with certain foreigners, promote factions within foreign courts (as Ashurbanipal does with an Elamite faction rival to Teumman), and accept tribute from submissive vassals. But in all of these positive or neutral interactions, the foreigners should be seen as 'enemies tamed': enemies who have correctly submitted to Assyria.

Any sharp conceptual division between Assyrian and enemy breaks down when Neo-Assyrian kings must report rebellions and civil wars. Internal rebellions and disunity threaten to collapse the entire order of the cosmos, and reporting on them often provokes unusual and innovative narrative styles and strategies. Most scholars agree that the unusual and potentially embarrassing circumstances under which Esarhaddon came to power, over the murder of his father and a war with his brothers, is the reason that Nineveh A is so distinctive a literary document (Tadmor 1983; Talon 2005; Hurowitz 2009; Knapp 2016). Esarhaddon's account of these events refuses to give the names of the brothers who allegedly murdered Sennacherib and against whom he subsequently fought for the throne, and does not report their actual crime; the murder that led to the war for succession, or even the fact that Sennacherib died, goes unmentioned. ${ }^{9}$

In the examples that follow, it will be clear that different circumstances necessitated different attitudes towards enemy speech. In both Nineveh A and Ashurbanipal's account of the campaign against Teumman in Prism Editions B,

9 Parpola (1980) has shown that the brother who murdered Sennacherib and led the fight for the throne must be Arda-Mulissi, remembered in the Hebrew Bible as Adrammelech. For more on the circumstances of his murder and the consequences of it, see (Wiseman 1974; Frahm 1997: 18-19, 21; Grayson and Novotny 2014 (RINAP 3/2): 26-29). 
D, C, Kh, and G, the possibility that enemy words or deeds could undermine the legitimacy of Assyrian kings necessitates a divine intervention. Divine direct speech, documenting real oracular answers, can counter enemy threats. Finally, enemy speech itself can be transformed to perform the same function, as enemies in defeat testify to the omnipotent might of the Assyrian king.

\section{Direct speech in Esarhaddon's Nineveh A}

The text designated Nineveh A (RINAP 4 1; Borger 1967: 36-64; Campbell Thompson 1931: 8-28), also called the Thompson Prism, contains an edition of Esarhaddon's annals dating probably from the summer of his eighth regnal year, in 673 BCE (Knapp 2016: 183-84; Tadmor 1983: 45). The text is most famous for a section comprising approximately the first sixth of the whole, usually called 'Esarhaddon's Apology' after an influential identification by Tadmor (1983). The Apology describes in great detail, and with unusually elaborate literary language, the circumstances of Esarhaddon's accession to the throne after the murder of his father and a contest for control with his brothers. This aspect of the text has made it highly interesting to scholars for historical purposes, but it has also received a great deal of scholarly attention as literature; the entire composition, and not just this first sixth, is distinguished by unusual and intriguing literary features (Hurowitz 2009; Talon 2005; Gerardi 1989; Pongratz-Leisten 2015: 341-45).

Most scholars have accepted Tadmor's influential suggestion that Nineveh A, with its unusual Apology and its concern with royal succession, was created in order to prepare the way for Ashurbanipal's nomination as crown prince (Tadmor 1983). ${ }^{10}$ More recently, Knapp (2016: 186-87) has placed the impetus for its composition in the defeat suffered in Esarhaddon's campaign against Egypt in 674. This defeat, along with other misfortunes, may have called Esarhaddon's legitimacy into question and created a context in which it seemed necessary to re-establish the legitimate basis of his kingship. The first exemplars of the text were created early in 673 , about ten months before ceremonies to establish succession arrangements were held, and other exemplars were created throughout 673 and into 672 (Lauinger 2015: 290). What is certainly clear is that

10 It is unclear whether his nomination would have been controversial. Like Esarhaddon, Ashurbanipal was a younger son. Although it seems that succession by the eldest son was the default expectation, it was 'by no means obligatory' (Weissert 1998, PNA 1/I: 163). Esarhaddon's plans for Ashurbanipal to succeed to the throne of Assyria while his brother Šamaš-šumu-ukin took the throne of Babylon was, however, certainly a novelty. 
the text is in dialogue with difficult political circumstances of this mid-late period of Esarhaddon's reign which included not only unusual succession plans and the military setback in Egypt (which would be successfully conquered a few years later in 670; Knapp 2016: 186, 190), but also Esarhaddon's worsening health, potential internal rebellions, and Esarhaddon's growing fear of more of them (see Radner 2007).

What is most interesting about the text for our purposes is the relatively large amount of direct speech involved in the Apology. Table 1 summarises the eight examples of what I consider direct speech in the text. All but the last two of these examples occur during the Apology section; it is unsurprising to find an unusual narrative feature in this unusual section of the text. For my purposes here, it needs to be noted that only one of these eight instances in Nineveh A, occurring after the Apology, is speech attributed to enemies. One other comes from Assyrian soldiers who had formerly supported Esarhaddon's brothers (but are quickly forgiven this mistake, and never understood as criminal for their brief poor choice). Nonetheless, the uses of direct speech in this composition, not just by enemies, can serve as a useful way into the topic.

In a 1989 article, Gerardi comprehensively analysed instances of direct speech in Nineveh A and in Esarhaddon's so-called 'Letter to the God'. She argues, entirely convincingly, that direct speech in royal inscriptions is used to justify and explain unusual actions. The direct speech in Nineveh A, she explains, provides 'supporting documentation' (Gerardi 1989: 249). The statements conveyed in direct speech do not add new narrative information or push the 'story' forward. Instead, they provide direct access to information that the narrator has already given us. ${ }^{11}$ Speech is used primarily to preserve legally important statements or memorable speech. These are the types of statements that I would consider to usually represent quotations, in one sense or another.

Gerardi further convincingly shows that speech within the Apology section of the text follows a chiastic structure as follows:

\section{Sennacherib \\ Gods \\ Esarhaddon \\ Esarhaddon \\ Gods}

Repentant Assyrian soldiers

11 This is in stark contrast to the use of speech in the 'Letter to the God', where lengthy quotations from letters between Esarhaddon and the king of Šubria constitute almost the entire narrative (Gerardi 1989: 253-57). 
This structure, and the content of the 'supporting documentation' conveyed in each instance, make a powerful case for Esarhaddon's legitimacy. Sennacherib at one end, and the Assyrian soldiers who had considered rebellion at the other, indicate the legitimacy of Esarhaddon as king, 'politically' (through human mouths). The gods, through signs in animal livers then interpreted through the medium of human diviners, confirm this legitimacy (supporting the succession and taking Esarhaddon's side in warfare). In the middle is Esarhaddon, left pondering his brothers' ungodly treachery to him and crying out in woe, in a way that is likely a direct entreaty to the gods - an entreaty answered with their military support.

The first of these instances, Sennacherib's statement about the succession, can surely count as quotation (RINAP 41 i 10-12):

My father, my begetter, in the assembly of my brothers, firmly raised my head, (saying) thus: 'this is the son who is my successor'

abu bānûya

ina puhur ahhiya rēšiya kēniš ullima

umma annû māru ridûtiya.

The text preserves in essence a pronouncement that we are told was made publicly 'in the assembly', and before the brothers who will usurp. In fact, this pronouncement must have been made in various contexts, including presumably in 'succession treaties' like those more famously drawn up by Esarhaddon for his own heirs, and which are probably being referenced here. ${ }^{12}$ We will come to the extraordinary power of succession treaties in a moment, but in any context, such words coming from a king had performative power. By verbally (or textually) indicating that it was his wish that Esarhaddon succeed him, Sennacherib immediately made this true: Esarhaddon became heir.

The two instances of divine direct speech, in each case specified as received through divination, are also powerful and also must represent quotations of some sort, preserving real oracular answers. The confirmation of Esarhaddon as successor is explicitly said to be obtained through biru. This term refers specifically to the art of the haruspex, the liver diviner. The later confirmation of divine support for Esarhaddon in battle would have been obtained the same way (the word used for the omens received is širu, written with the logogram UZU, literally 'flesh'). The phrasing used to describe both oracular answers, a 'firm yes' (annu kēnu), is a technical term found in divination queries, almost always referring specifically to liver divination.

12 We do know of one such treaty (SAA 2 no. 3), in a fragmentary state, which presumably was to secure Esarhaddon as crown-prince. 
Baruchi-Unna (2017) has considered instances of the 'firm yes' in Assyrian royal inscriptions alongside the phrasing of extispicy queries and reports. Extispicy reports, recording the answers to queries, yield only a one or twoword result to a binary query (țāb for 'favourable'; laptu or ul țābu for 'unfavourable'; lā parsu for indecisive). In only two of 76 extispicy reports dating to the reigns of Esarhaddon and Ashurbanipal is the substance of the query rephrased as a sentence following this result (Baruchi-Unna 2017: 345). ${ }^{13}$ The full sentence responses of the gods quoted in Nineveh A are then hard to imagine in an extispicy report. Baruchi-Unna (2017: 361-62) points out that the second, longer divine quotation would have had to involve rephrasing of multiple queries. Clearly a further level of interpretation has been added by the authors of the royal inscription that would not have been present in a written extispicy report. $^{14}$

It is likely then that the Nineveh A authors did not literally seek out tablets that had been produced in conjunction with an extispicy. However, the use of such specific divinatory terminology and the direct speech have the same overall effect as a 'faithful' quotation: most likely, a real query was performed, in the appropriate way, and this was the answer. In extispicy, there are already layers of interpretation and rephrasing involved in the process of getting a 'firm yes'. In Assyria, a 'quotation' can be different in wording, genre, structure, or medium and yet still be accurate, since in Mesopotamian thought one sign, word, or event can often be accurately understood in many ways (see for an overview, Bahrani 2008: 57-74). In this case, the gods' 'speech' is made through markings on the liver of a sheep. A degree of interpretation and translation by the diviners must take place to determine whether the answer is favourable or unfavourable, and this, if needed, can then be further explained verbally or in writing.

The closing segment of the chiastic structure is the speech by Assyrian soldiers who transfer their allegiance from the usurping brothers to Esarhaddon. Through the intervention of the goddess Ištar, who stands by Esarhaddon, the brothers' armies have been failing - the meaning of which, the narrative tells us, the soldiers of those armies grasp: 'In their assembly, they spoke thus, saying: “This [i.e. Esarhaddon] is our king!” (ina puhrišunu iqbû umma annû šarrāni; RINAP 41 i 77). After speaking thus, at Ištar's command, the

13 For such queries and reports, see SAA 4 (Starr 1990).

14 Comparing extispicy reports to more comprehensive astrological reports, Robson (2011: 618) suggests that the analysis and explanation of extispicy findings (the necessary final stage of the process) must have happened with the diviners appearing before the king in person. She argues that this must have been a regular matter of routine for liver divination, since liver diviners, unlike scholars of other specialties, are not represented writing to ask for a royal audience. 
soldiers of the usurping brothers begin defecting to Esarhaddon's side. These misguided Assyrians are not truly enemies and are not seemingly punished for having initially supported the wrong side in the succession. However, their statement works in a similar way to statements of defeated or surrendering enemies (as we will see later): it testifies to the power and legitimacy of the king as opposition crumbles before him.

The final two examples of direct speech appear later in the text, not as part of the Apology. One of these is the fascinating 'victory chant' of Esarhaddon's victorious soldiers, which has been discussed in detail by Tadmor (2004). Tadmor (2004: 269) convincingly argues that the passage was a real chant performed during victory celebrations after successful campaigns against the kings mentioned, Abdimilkutti of Sidon and Sanduaru of Cilician cities Kundi and Sisu. The chant was remembered and ultimately made its way into Esarhaddon's written annals. If this is true, which seems likely, then this is another quotation of prior speech. It is not hard to see why and how the words were remembered. Catchy as the chant is (in Akkadian and English alike), there would be no need of textual preservation for the couplet to survive in memory years after the procession and ultimately for a scribe to decide to include it along with the prose descriptions of the triumph over these enemies.

Finally, we come to another poetic triumph over enemies - although this time one put in their own mouths. Hurowitz (2009: 144) has identified the section of Nineveh A from which this final instance of direct speech comes as another distinct composition integrated into the wider narrative (as is the Apology). He describes it as 'poeticised prose', a pseudo-hymn which celebrates Esarhaddon in language that echoes the terms of known Assyrian coronation hymns. This led Hurowitz (2009: 138-42) to propose that this section preserves memory of a real hymn created for that occasion. At this date, only certain aspects of that hymn are remembered, chiefly Esarhaddon's titulary. If we accept this suggestion, this too is then an example of quotation of a type, at least of reference-by-memory to the contents of a text that might have been composed for Esarhaddon's own succession.

The pseudo-hymn gives its final words to the enemies of Esarhaddon:

From the midst of the sea, my enemies cry out, saying:

'Where can a fox go to get away from the sun?'

ultu qereb tâmtim nakrīya kīam iqbûni

umma šēlabu lapān Šamaš èkiam illak

Pongratz-Leisten (2015: 145) uses this quotation in her Religion and Ideology in Assyria as an opening to a chapter on 'Empire as Cosmos, Cosmos as Empire' 
and the ideology of 'universal control'. It is a well-chosen epigraph for the topic, elegantly expressing the conception of the borderless empire Assyria must create. Esarhaddon, equated to the sun (and therefore to the god Šamaš, the terms and concepts being interchangeable), ${ }^{15}$ is everywhere, all-seeing, and unavoidable - even by the lowly burrow-dwelling fox. ${ }^{16}$ The speech glorifies Esarhaddon as it denigrates the speakers: if Esarhaddon is the sun god, his enemies are a foolish, small, slinking, hiding animal.

Like the rest of the pseudo-hymn, the statement is unusually poetic. It is most likely that it represents a proverb, quoted here in part or full. We cannot relate it to any known proverb preserved elsewhere in the literary tradition, but this does not necessarily mean that no such proverb existed. Quotation of proverbs is common in Neo-Assyrian letters (Lambert 1960: 280-82; Parpola 1983: 15). Many of the proverbs referenced in these contexts are not attested in literary collections. Alster (1996: 16-17) has suggested that such Akkadian proverbs, which are not recognisably translations of Sumerian ones, were perhaps authentic parts of 'daily speech', as opposed to the archaic and literary Sumerian proverb tradition, copied by scribes in Sumerian-Akkadian bilinguals in this period. ${ }^{17}$ Although we cannot be certain how foxes were regarded in a distinctly Akkadian proverb tradition, in the Sumerian proverbs the fox is usually a foolish or prideful figure. If so, the choice of the fox might be intended to highlight the obvious futility of even asking, let alone answering, the rhetorical question here: only a fool would think they could escape Assyrian royal power. ${ }^{18}$

Here then, we most likely have speech that references another literary genre tradition, just as the references to divination queries and victory chants do. There is a reference outside of the text in this speech then, but it should not be described as 'quotation' of real enemy words in any meaningful sense. These are enemies in the abstract: unnamed, extracted from any specific historical

15 The implicit or explicit comparison of the king to the sun is made in letters as well, as Parpola notes (1983: 130); for a fuller discussion of the association of the sun, and other celestial bodies, with the Assyrian king, see Frahm 2013.

16 Elsewhere in the text, Nabû-zēr-kitti-līšir, son of Marduk-apla-iddina II, is compared to a fox as he flees in fear from the Sealand to Elam (RINAP 41 ii.54-55). Hurowitz (2009: 150-51) considers this second mention of the fruitlessly fleeing fox one of a number of ways in which the pseudo-hymn calls back to earlier passages of the text.

17 For examples of these bilinguals, see the ORACC project Bilinguals in Late Mesopotamian Scholarship: http://oracc.museum.upenn.edu/blms/.

18 Lambert, who was the first to suggest that this represented a potential reference to a proverb, further suggested that it might possibly reference a folk tradition in which the fox and the god Šamaš were enemies (Lambert 1960: 282). 
conflict, who speak in literary references. Returning to the earlier discussion of the centrality of enemies to Assyrian self-construction, it should be considered just how striking it is that enemy voices close this hymn about Esarhaddon's legitimacy. Who better to know whether an Assyrian king is truly a king than his defeated, despairing enemies, unable to resist his supremacy?

Finally, I would like to consider the significance of speech, and especially hostile speech, in this latter stage of Esarhaddon's reign through a brief discussion of the well-known composition usually designated the 'Esarhaddon Succession Treaty' (EST) (SAA 2 (Parpola and Watanabe 1988) 6; Wiseman 1958; Grayson 1987; Parpola 1987; Lauinger 2012). There are eleven surviving exemplars of this text (with certain variations among exemplars). These were apparently mass-produced in a short period of time early in 672, in the month Ayyaru (II) according to colophons (Lauinger 2015: 291), and distributed around the empire. Lauinger (2015: 287-90) estimates that 110 in total would have been produced, in order to cover 71 provinces and 39 client kingdoms of the Empire. Fales (2012: 148-149) put it even higher, estimating, though he acknowledges it is a rough guess, approximately 200 copies must have been produced. ${ }^{19}$ The texts formed part of a concerted effort to bind vassals and high officials of the empire to Esarhaddon's succession arrangements, in which Ashurbanipal would succeed to the kingship of Assyria, and his older brother Šamaš-šumu-ukin to kingship in Babylon. Although this arrangement was unusual, such succession adê (the Akkadian term, and preferable to the slightly misleading 'treaty') were not a new invention; as already discussed above, a similar 'Sennacherib Succession Treaty' exists in a fragmentary state, probably ensuring Esarhaddon's right to the throne. The existence of such a 'Sennacherib Succession Treaty' is what should probably be understood by Nineveh A's reference to Sennacherib's designation of Esarhaddon as crown-prince. Of course, the treaty did not stop the rebellion of the brothers, but it does create the condition of their criminality. Their crime is to have violated this adê and the intentions expressed by it.

These adê, although they come to us as written texts, derived their power from a ritual in which they were transformed into 'Tablets of Destiny'. ${ }^{20}$ These rituals clearly involved performing certain actions, and speaking aloud words

19 His number is so much higher than Lauinger because he estimates a number of copies would have been produced for “'inner” professional groups' and for major cities of the Assyrian heartland (Fales 2012: 148 n. 96).

20 Most of our knowledge of adê derive from so-called 'chancellery copies' which were stored at Nineveh or Assur and were abbreviated copies or drafts, not the actual object over and through which the binding ritual was performed. The eleven EST exemplars are the only adê known to us not from copies but from their so-called țuppi adê, which were ritually transformed into Tablets of Destiny. 
that bound the parties to its terms. This is clear from the text itself, which references those acts occurring around (ritual actions) and through (ritual recitation) the written text on the tablet. The connection between spoken words and written words is then clear, as is the fact that the two work together in powerful ways. By speaking certain words, parties complete the ritual, at the end of which the tablet stands as a physical object, displayed in a temple, which keeps those words 'alive' and meaningful. The importance of the EST exemplars as objects is clear in their format; they are large tablets (approximately 45 by $30 \mathrm{~cm}$; Lauinger 2015: 287-88) impressed with the large cylinder seal of the god Assur (the socalled 'Seal of Destinies').

Equally interesting in this context is the EST's overwhelming emphasis on negative speech as crimes which must be reported and punished. This includes, obviously, speech about plots to murder Esarhaddon or Ashurbanipal (SAA 26 o 73-86, 108-22, 212-13), but also 'slander' (karșu) or 'not good' (la țābtišunu) speech, speech that stirs up discord among the royal family and the court, or expresses an unsuitable internal attitude towards the king and his heirs (o 269282, 318-327, 336-352). There is an obligation to report speech, before the evil intent it indicates can be acted upon (SAA 26 o 73-82): ${ }^{21}$

If you hear any improper, unsuitable or unseemly word concerning the exercise of kingship which is unseemly and evil against Assurbanipal, the great crown prince designate, either from the mouth of his brothers, his uncles, his cousins, his family (var. His people), members of his father's line; or from the mouth of magnates and governors, or from the mouth of the bearded and the eunuchs, or from the mouth of the scholars or from the mouth of any human being at all, you shall not conceal it but come and report it to Assurbanipal, the great crown prince designate.

šumma attunu abutu lā țābtu lā banītu

lā tarissu ša epēš šarrūte ša ina muhhi Aššur-bani-apli

mār šarri rabiu ša bìt-rēdûte lā tarșatūni lā țābatūni

lū ina pî ahhēšu ahhē-abbēšu mār-ahhē-abbēšu

qinnišu zār bìt-abǐšu lū ina pî rabiūti pāhāti

lū ina pî ša-ziqni ša-rešāni

lū ina pî ummânī lū ina pî naphar șalmāt qaqqadi

mala bāsû tašammāni tupazzarāni

lā tallakāninni ana Aššur-bani-apli mār šarri rabiu

ša bìt-rēdûti lā taqabbāni

Sometimes the plots fomented by these potential insurrectionists might themselves involve inciting further evil speech (SAA 26 o 336-346):

21 All quotations from SAA 26 are in the translation of Parpola and Watanabe 1988. 
If someone involves you in a plot, be it one of his brothers, his [unc]les, his relations, a member of his father's line, a e[unuch] or a bearded (courtier), an Assyrian or a foreigner, or any human being at all, saying: "Slander his brothers, sons by his own mother, before him, make it come to a fight between them, and divide his brothers, sons of his own mother, from him", you shall not obey nor speak evil about his brothers in his presence, nor divide him from his brothers.

šumma memmēni ušakpadūkanūni iqabbakkanūni issu libbi ahhēšu ahhē-abbēšu mār-ahhē-abbēšu qinnīšu zār bìt-abišu lū ša-rēši lū ša-ziqni lū mār Mat-Aššur lū mār māti sanīnimma lū ina naphar șalmāt qaqqadi mala bāsû iqabbakkanūni mā karșī ša ahhēšu mār ummišu ina pānīšu akla mā šamhișa ina birtuššunu mā ahhēšu mār ummī̌su issu pānišu pursa attunu tašammāni lā țābtu ša ahhēšu ina pānīšu taqabbāni issu pān ahhēšu taparrasāšūni

It should be noted too here that the treaty makes extensive use of direct speech itself, quoting these imagined, potential future evil-doers directly, and also formulating in precise words the correct response (SAA 26 o 347-352):

You shall not let those who speak such things go free but shall come and report to Assurbanipal, the great crown prince designate as follows: 'Your father imposed a treaty on us and made us swear an oath concerning it'.

šumma qābiānu ša abutu annītu iqbakkanūni turammāšūni šumma lā tallakāninni ana Aššur-bani-apli mār šarri rabiu ša bìt-rēdûte là taqabbāni mā abūka adê ina muhhīka issīni issakan uttammannāši

And lest anyone attempt to undermine this oath through devious speech, the treaty forbids such an action (surely liable to trigger the curses contained at the end) (SAA 26 o 385-387):

While you stand on the place of this oath, you shall not swear this oath with your lips only but shall swear it wholeheartedly.

šumma attunu kî (ina) kaqqar tamiti annitu

tazzazāni tamītu ša dabābti šapti

tatammāni ina gummurti libbikunu lā tatammāni

Any Near Eastern king would recognise that hostile words are not to be treated lightly, since they have the potential to begin hostile actions. But slander and 
evil words are enough already to convict an offender under the terms of this treaty. These provisions accord with Esarhaddon's apparent anxiety towards the end of his reign with slander and negative words from within his court and around his empire (see Frahm 2010: 131-33; Knapp 2016: 186-87) - a not unjustifiable fear, after a well-documented attempted revolt led by a figure called Sasî in 670 (Radner 2007).

In the discussion of Ashurbanipal's sources to follow, it will become apparent that it was not only Esarhaddon who saw speech as a potent criminal act, and that this idea was expressed not only in adê texts. In Nineveh A however, Esarhaddon does not allow enemies this dangerous privilege and neuters their threat: the words he puts in their mouths show them entreating him in despair and testifying to his omnipotent power. This omnipotence was something that the EST tried to make a practical reality, by asking that any enemy thought or speech was immediately revealed to the king. ${ }^{22}$

\section{Ashurbanipal's accounts of campaigns against Teumman and his allies}

Like Nineveh A, Ashurbanipal's various royal sources narrating his campaign against Elamite king Teumman in 653 have a number of unusual and innovative features. ${ }^{23}$ In sources created between late 653 and c. 642, Ashurbanipal told the story of the defeat of Teumman and his allies in Elam and in southern Babylonia in various, interrelated texts and images. ${ }^{24}$ I will focus on direct speech and mentions of speech in a few different Ashurbanipal text editions, and in the Southwest Palace reliefs and their accompanying epigraphs. I want to consider not only the instances of direct speech, but also the significance of enemy speech as a crime against Assyria - as we have also seen in the context of EST.

22 This apparently really did happen before and in the aftermath of Sasî's revolt (Radner 2007: 174; Wiseman 1974: 150).

23 For Ashurbanipal's prism inscriptions see RINAP 5/1 3-11; Borger (1996: 1-257). For relevant reliefs see Barnett 1976; Barnett et al. 1998 (rooms XIX, XXII, XXVIII, XXXIII). For epigraphs on reliefs and the related, so-called 'epigraph tablets', see Weidner 1932-1933; Gerardi 1988; Barnett et al. 1998: 94-100; Russell 1999: 158-164; RINAP 5/1 24-58.

24 On the historical background to the conflict with Teumman, and the tension between Assyria and Elam in this period, see Gerardi 1987: 120-157; Waters 1999, 2002: 42-80; Novotny and Jeffers 2018 (RINAP 5/1): 20-25. 
Ashurbanipal's Prism B, composed in 649, is the earliest edition of the annals to feature an account of the campaign against Teumman (a substantially identical description of the campaign would appear in later Prism editions D, C, Kh, and G). ${ }^{25}$ This account centres significant instances of direct speech in its treatment of the events leading up to battle at the Ulai River in which Teumman is killed. The threatening nature of enemy speech is already apparent in Ashurbanipal's preemptive campaign summary (RINAP 5/1 3 iv 80-87):

In my seventh campaign, I went out against Teumman, king of Elam, who had repeatedly sent his emissaries to me concerning Ummanigaš, Ummanappa, (and) Tammaritu, sons of Urtak king of Elam, (and) Kudurru (and) Parru, sons of Ummanaldaš, brother of Urtak king of Elam, asking me to send back those people who had fled and grasped my feet.

ina sebê gerriya eli Teumman šar elamti

lū allik ša eli Ummanigaš Ummanappa

Tammaritu mārī Urtaki šar elamti

Kudurru Parru mārī Ummanaldaše

ahi Urtaki šar elamti

șirūtišu ištanappara ana šēbuli

niši šâtunu ša innabtūnimma

iṣbatū šêpìya.

Ashurbanipal had given sanctuary to members of the Elamite royal family displaced by Teumman's usurpation (he is the third of three brothers to take the Elamite throne; see Waters 1999: 474, 2013: 480-81). The aggressive and 'insulting messages' (šipir mērehti) asking for their return had been sent monthly by the hands of a certain Umbadarâ and Nabû-damiq, who will appear later on in Prism Edition B as well as in epigraphs and reliefs, suffering for this act (RINAP 5/1 3 vi 48-56). Inside Elam, Teumman was 'puffing himself up in the assembly of his troops' (uštarrah ina puhur ummānātišu; RINAP 5/1 $3 \mathrm{v}$ 1). Already enemy speech, and its tendency to provoke, is at the heart of the conflict. Putting his trust in Ištar, Ashurbanipal does not comply with Teumman's 'provocative' (erhu; RINAP 5/1 3 v 3) demands to send back the fugitives. His trust in divine support is rewarded; the gods have already judged Teumman, and indicated their unfavourable plans for his future through an astral omen and a stroke that Teumman suffers (see Collins 2006).

Another text preserved on a tablet fragment (K.8016, published by Livingstone 1989 as SAA 3 31) seems also to narrate this moment, giving further details of Teumman's threatening and hubristic speech (SAA 331 o $7^{\prime}-13^{\prime}$ ):

25 On this dating see Piepkorn 1933: 19-27; Grayson 1980b: 245; Gerardi 1987: 57-58; Novotny 2003: 211-15; Novotny and Jeffers 2018 (RINAP 5/1): 27-36. Five tablets which may be early drafts with descriptions of the battle at Til Tuba also exist; see Borger 1996: 101-103. 


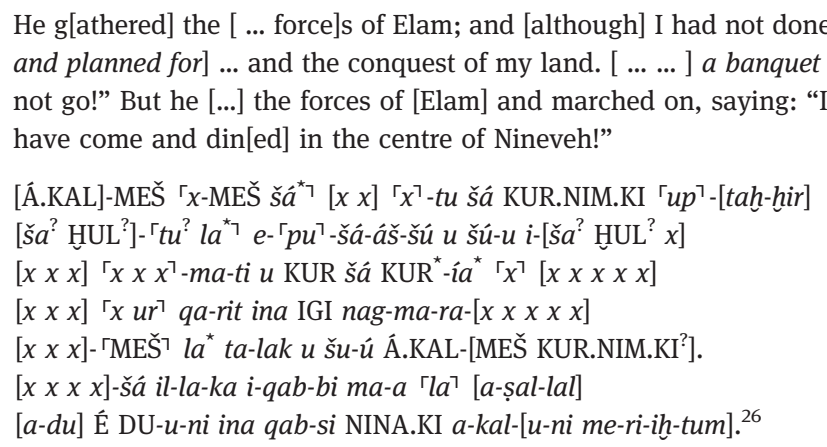

Gilibert (2018) has suggested that Teumman's aggressive boast is referenced in the famous 'Garden Party' relief of Ashurbanipal. Teumman's threat to dine in the centre of Nineveh comes true, but not as he intended it: his severed head hangs in a tree while Ashurbanipal and his queen banquet in their palace garden. This is a comeuppance that Gilibert identifies as consistent with Frahm's understanding of Assyrian humour as consisting of dark, ironic reversals (Frahm 1998: 156-58; see also Reade 2005: 7-8). It also suggests that Teumman's threatening speech must be indexed in his punishment. ${ }^{27}$

In Prism Edition B, Teumman's threatening words are filtered through a further layer of direct speech, given in the report of an Assyrian messenger to Ashurbanipal. While Ashurbanipal is in Arbela during the month of $\mathrm{Ab}$ to participate in a festival revering Ištar of Arbela, he receives the distressing news. Here we have a quotation from a messenger, with another quotation embedded within it, quoting the speech of Teumman. The messenger says (RINAP 5/1 3 v 21-24):

Teumman - the counsel of whose mind Ištar had altered - spoke thus, saying: "I will not leave until I have gone and made battle with him."

... m teumman

kīam iqbi ša ${ }^{\mathrm{d}}$ ištar ušannû milik țēmešu

umma ul umaššar adi allaku ittišu

eppušu mithușūtu

What follows is a highly unusual interlude in which Ashurbanipal, distressed by the report of Temman's hostile words, offers a prayer to Ištar. This long, highly

26 Transliteration and translation following SAA 3 31; not normalised because of the fragmentary nature of the text.

27 On 'indexing' as a common feature of corporal punishment cross-culturally, see Geltner 2014: $26-27$. 
literary prayer is quoted at length, in direct speech. Ashurbanipal is then granted a vision of Ištar and more importantly an 'auditory' visitation, in which he hears her response to his prayer. ${ }^{28}$ This also is quoted at length, in the goddess's own words. This is followed immediately by an account of a second appearance of the goddess, this time one in which the means of communication is specified (RINAP 5/1 3 v 48-49):

During that same night that I faced her [i.e. Ištar], a certain dream interpreter lay down and saw a dream.

ina šāt mūši šuātu ša amhurši

ištēn šabrû utūlma inațtal šuttu

The dream interpreter reports this dream to Ashurbanipal, a report which is once again quoted in direct speech, the dream interpreter giving a lengthy and vivid description of a vision of the goddess and Ashurbanipal in contact (RINAP 5/1 3 v 50-55):

He awoke and repeated to me the night-vision which Ištar had caused him to see saying: 'Ištar who dwells in the city of Arbela entered; on the right and the left she was adorned with quivers. She was holding a bow at her side, she was unsheathing a pointed sword, which was (ready) to make battle. You stood before her; she was speaking to you just like a birth-mother.

iggiltima tabrìt mūši ša Ištar ušabrûšu ušannâ iâti umma Ištar āšibat Arba-ili èrubamma imna $u$ šumēla tullâta išpāti tamhat qašti ina idiša šalpat namșāru zaqtu ša epēš tāhāzi maharša tazziz šì kìma ummi ālitti ìtammâ ittika

The dream interpreter then quotes a dialogue between the two in which Ištar promises that she herself will set out against Teumman. Ashurbanipal asks to go with her, to which Ištar makes an interesting reply (RINAP 5/1 3 v 56-69):

The goddess Ištar, the sublime one of the gods, summoned you, she established her decision, saying: 'You are looking towards doing combat; I myself am about to set out

28 How and in what context Ashurbanipal hears this assurance is not made explicit. Oppenheim (1956: 200) presumes that Ashurbanipal himself has a vision, although one in which he, in his humble posture, cannot see the goddess, but experiences her real presence. I think it is more likely that the account is abridging a means of ritual communication with the goddess, in which an intermediary process returned this answer, paralleling the second theophany of Ištar in a dream. 


\begin{abstract}
ilsika Ištar šaqût ilāni išakkanka țēmu
umma tanațțala ana epēš šašme

ašar pānū'a šaknu tēbâku anāku

attā taqabbiša umma ašar tallakī

ittiki lullik bēlet bēlēti

šì tušannâkka umma attā akanna lū ašbāta

ašar maškanika akul akalu šiti kurunnu

ningûtu šukun nu' id ilūtī

adi allaku šipru šuātu eppušu ušakšadu

șummerāt libbika

pānūka ul urraq ul inarruțā šêpīka

ul tašammaț zūtka ina qabal tamhāri

ina kirimmiša țābi tahṣinkama tahtena gimir lānika

pānušša gīri innapiȟ.
\end{abstract}

towards my destination (the battlefield)'. ${ }^{29}$ You spoke to her, saying: 'The place you are going to, let me go with you, lady of ladies!' She replied to you, saying: 'You will (stay) sitting here, in the place where you are settled: eat food, drink beer, make joyful music, be attentive to my divinity, until I have gone (and) done this work; I will make (you) achieve the desire of your heart. You will not cause your face to pale, your feet will not tremble, you will not wipe away your sweat in the midst of battle.' She hugged you into the sweet crook of her arm, she protected the whole of your form. Before her, fire flared up.

The dream interpreter finishes by explaining that he saw Ištar set off against Teumman. Further, within this report, the dream interpreter quotes a multi-part dialogue between the dream-Ištar and dream-Ashurbanipal. When the dream report ends and we return to the voice of Ashurbanipal-as-narrator, he is reassured, and puts his faith in the goddess.

The significance of quotation and speech within this passage is obvious. At the moment that the dream-appearance Ištar speaks, we have Ashurbanipal (the narrator of the entire text) quoting a report of a dream interpreter quoting his dream in which Ištar spoke. An interest in oracular dreams is a feature of Ashurbanipal's inscriptions, with the occurrence of meaningful dreams mentioned in four separate incidents in his texts, and in no other Neo-Assyrian inscriptions (Oppenheim 1956: 187). Of these, only this dream is rendered in such vivid narrative detail and style. Although not stated directly, most likely the text describes a provoked dream - a similar situation to the provoked, extispicy-derived divine speech in Nineveh A. The dream interpreter would have staged a ritual with the hope of receiving a dream message from Ištar around the same time that Ashurbanipal offered his prayer, as a corollary to that activity.

29 For the translation of this statement of Ištar, I have followed Jeffers and Novotny's translation exactly. 
Zgoll (2014: 310-313) argues that 'message dreams' in which deities give clear, unambiguous instructions, like the one reported here, are already a product of interpretation; the dream interpreter receives a dream composed of unclear images (as Mesopotamian dreams reported in other contexts consist of) and interprets it into a clear and unambiguous message from the deity. We do not hear about this step because the dream-interpreter's report as rendered through his specialist knowledge is the 'true' meaning of the dream. As with the 'firm yes' of Esarhaddon's Nineveh A, divine oracles can go through many layers of rephrasing while remaining fundamentally a true quotation. Like those much shorter speeches of the gods in Nineveh A, the text here is probably quoting from a real response received through divination, and already representing a translation, of coded messages, rendered into narrative Akkadian. I think that we can presume that the dream, as reported here, was a real event and was really reported to Ashurbanipal in such terms by a dream interpreter. The message of Ištar needed to be preserved just as received (RINAP 5/1 $3 \mathrm{v}$ 75): 'the message of Ištar my lady that cannot be changed' (šipir Ištar bēltiya ša lā innennû).

Later editions of the annals, Prisms $\mathrm{F}$ and $\mathrm{A}$, leave out this extensive quotation of Ashurbanipal's prayers to Ištar and the dream vision she sends in response. This must be in part because of the need to shorten accounts of earlier campaigns to make room for narratives of subsequent ones. Later annals editions do add extensive quotation of enemy direct speech by a repeatedly troublesome successor Elamite king, Tammaritu, initially installed by Ashurbanipal from among the Elamite nobles who had sought sanctuary from Teumman at the Assyrian court. Tammaritu's criminal utterances are quoted in several contexts, and the act of speaking them linked to subsequent humiliations he suffers. Tammaritu's support for Šamaš-šumu-ukin in his civil war with Ashurbanipal is seemingly less important than two reported instances of 'insults' (mêrehti) (RINAP 5/1 11 iv 12-27):

Concerning Tammaritu, the king of the land of Elam, who had spoken insults concerning the cutting off of the head of Teumman, which a common soldier of my army had cut off, saying thus: 'Will they cut off the head of the king of the land of Elam in his (own) land, in the assembly of his troops?' He further spoke thus: 'Moreover, how could Ummanigaš kiss the ground before a messenger of Ashurbanipal, king of Assyria?' On account of these words which he had slanderously uttered, Aššur and Ištar attacked him, and Tammaritu, his brothers, his family, the seed of his father's house, along with 85 nobles who march at his side, ran off from before Indabibi, they crawled on the ground in their nakedness and came to Nineveh. 


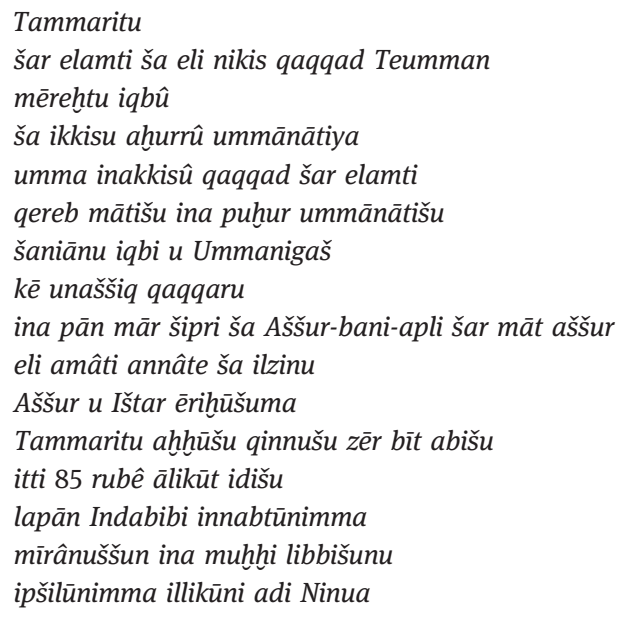

The reported statements do not explicitly urge aggression against Assyria; it is the mocking and disrespectful nature of his speech that needs to be punished, with a humiliating comeuppance in which he and his family far exceed a mere 'kissing the ground'. Most likely these statements were reported to Ashurbanipal by his own partisans, who correctly understood that this was just the sort of slander and trouble-stirring that the EST made it mandatory to report. ${ }^{30}$

Tammaritu's speech is monitored even more closely in subsequent acts of disrespect: the text also reports on his thoughts, quoting words he had spoken 'to his own heart' (ana libbišu). Once again, these criminal words reflect Tammaritu's threatening sense of his own dignity (RINAP 5/1 $11 \mathrm{v} 26-28$ ):

The people of the land of Elam have turned into women. Who are they in the face of Assyria? They (the Assyrians) constantly come in and plunder the loot of the land of Elam.

nišì elamti ana sinnišāte itūrū

ina pān māt ǎšsur šunu šunuma irrubūnimma

ihtanabbatū hubut elamti

Always on guard, Aššur and Ištar detect the 'danger' (ekșu) of Tammaritu's internal speech and intervene to force him to again capitulate to Ashurbanipal and to allow Ashurbanipal to do just what Tammaritu complained of, marching

30 It is also possible that these are quotations of something that Tammaritu said directly to Ashurbanipal; letters between the two did exist (SAA 21 119-121). However, I find it unlikely that Tammaritu would take such an openly aggressive tone while relations were still good enough for correspondence between the two. It is possible that these statements were made to allies in letters, who subsequently reported to Ashurbanipal on them. 
about victoriously in Elam. ${ }^{31}$ This cannot be any sort of real quotation, though it is treated like one, as if the omnipotence of gods extends to Ashurbanipal-asnarrator, able to see into the hearts of enemies and catalogue their rebellious internal monologues.

Moving from these narrative texts and back to the initial conflict with Teumman and his supporters, I would like to consider enemy speech in the Southwest Palace Room XXXIII reliefs and related epigraphs. Here we find several instances of enemies, allies of Teumman, being punished for speech. The most significant of these involves a punishment imposed upon two nobles of the southeast Babylonian tribe of Gambulu, which was allied with Teumman against Assyria. The nobles, named as Mannu-kī-aḩhē and Nabû-uṣalli, are depicted twice each, having their tongues torn out and then being flayed alive (Barnett et al. 1998: Pl. 302). This moment is also described in an accompanying epigraph (see RINAP 5/1 36), on several epigraph tablets (Russell 1999: 163), ${ }^{32}$ and in Prism B which explains that the two men, 'who had uttered grievous blasphem(ies) against my gods' (ša eli ilāniya iqbû šillatu rabīti; RINAP 5/1 3 vi 73; translation Novotny and Jeffers) received this gruesome punishment. We are not told what those blasphemies were. The word šillatu can indicate sacrilegious speech/behaviour or mere insolence/insult. Given the divine support behind Ashurbanipal, insults to him are also insults to the gods. The act of speaking words against Ashurbanipal or his gods leads to a punishment that indexes that very offense.

In a cross-cultural study of corporal punishment, Geltner (2014: 26-27) describes this type of punishment as 'perched between' indexing and mimesis, sometimes referred to as 'symbolic indexing' or 'ironic talion'. He identifies this kind of referencing as a primary feature of much of corporal punishment across cultures. The flaying that accompanies it is apparently less indexical, though it indicates the deathly seriousness of speaking šillatu rabiti. Although extraction of tongues is not a frequently reported Assyrian punishment, this is not the only place where enemy speech is indexed through reference to the enemy body. We see it also in Ashurbanipal's attack on a captive statue of the long-dead Elamite

31 The continued criminality and humiliating capitulations of Tammaritu must probably cover a situation in which Ashurbanipal was in fact not very successfully controlling Elamite rivals. Despite the claims that his hubris is always punished, he remains in power to trouble Ashurbanipal again.

32 The relationship between the epigraphs that appear on wall reliefs and the so-called 'epigraph tablets' (of which there are nine relevant to this sequence) is still uncertain. Should they be considered 'drafts' for reliefs, 'descriptions' of existing reliefs, or something else? For an overview and proposed chronology of composition, see Russell 1999: 187-99. 
king Hallušu, who had troubled his grandfather Sennacherib (Borger 1996: 5455; translation May 2014: 718-19): ${ }^{33}$

\author{
[his] nose which sneered, I cut off; his lips which spoke insolence, I sliced off; his hands \\ which grasped a bow to fight Assyria, I chopped off. \\ appi[šu] ša išnișșu akkis šaptišu ša iqbâ mērih̆tu apru’ \\ qāssu ukarrit ša qašti iṣbatu ana mithuṣi Aššur
}

That these indexical punishments are performed on a captured statue indicates the power of representation to preserve the individual depicted (although in this case Hallušu's preservation in image, rather than preserving his life for future honour, winds up making him vulnerable, even in death, to Assyrian corporal punishment). The formulation also leaves it entirely clear why each body part is punished - and indicates that sneering and speaking insolence should be equated with lifting the bow against Assyria.

It is also interesting here to consider Hurowitz's (2008) analysis of Sargon II's 'Letter to Aššur', in which he looks at how the text frames Ursa of Urartu's crime and Sargon II's mission against him. Hurowitz convincingly shows that the text uses literary allusions, puns, and callbacks to index Ursa's punishment to his offenses (Hurowitz 2008: 110-20). Although there is not space here to recount Hurowitz's entire argument, he shows that Ursa is guilty of two (parallel) faults: vainglorious speech and trespass into Assyrian territory. Sargon II indicates that the purpose of his campaign is to 'shut up', in Hurowitz's term, the mouth of the enemy, and to bind his knees. Although neither of these things are literally done to Ursa, they are done figuratively: Ursa is last seen in the narrative issuing wailing cries of mourning from his mouth, squatting on the ground, while Sargon II carries off a statue of Ursa whose royal inscription now with unintended irony - proclaims Ursa's military successes. Ursa is punished both for his hostile military incursions into Assyrian space and for his hostile speech, at the same time and in both cases through the indexing on his body parts (mouth and knees, which Hurowitz shows are associated with trespassing movement). In the case of Ursa, his punishment, though clearly linked to his crimes, is not entirely delivered by Assyrian hands. In the punishments Ashurbanipal discusses above, to the Gambulian nobles and to the statue of Hallušu, Ashurbanipal or his soldiers themselves carry out the mutilation. But in all cases, the same parallelism between hostile or insolent speech and

33 Borger (1996) includes this text, K 3062+ 82-3-23,20 Rs. I., as an 'excursus' in his edition of the Prism class A and F. 
military aggression is at work, as is the mapping of these crimes onto the physical body.

Returning to the Southwest Palace reliefs, we find a final instance of punishment for enemy speech depicted within the same victory procession as the tongue-pulling, this one also described in an epigraph both on the walls and on separate epigraph tablets. The ambassadors of Teumman, Umbadarâ and Nabû-damiq, are forced to read out the same 'insulting messages' (šipir mèrehti) referenced in the Prism Edition B account, which they had brought on Teumman's behalf. Letters in the ancient Near East are always conceptualised as themselves 'quoting' spoken words of the sender. The act of bearing these letters (which perhaps these ambassadors themselves had read out at court when they were delivered) makes them complicit in a criminal speech act. Although we are never told what happens to these ambassadors after the forced re-reading of the letters, the incident features within a victory procession that includes humiliation, punishment, and execution, and the display of their sender's mutilated head. The crime of speaking insulting words is physically and conceptually equated with the punishments of tongue-removal, flaying, and decapitation; we must understand that the very words these ambassadors read seal their fates.

Finally, the Southwest Palace reliefs feature two other instances of enemy quotation, in the context of the heat of battle, each serving very different purposes from each other. The first example occurs in one of the epigraphs chronicling Teumman's desperate flight from the Assyria soldiers who will ultimately take his head. Injured in a fall from his chariot, Teumman is portrayed as wounded and pathetic - yet his foolishness and hubris are unchecked:

Teumman, in the loss of his reason, said to his son: 'Shoot the bow!'

Teumman ša ina miqit țēme

ana aplišu iqbû

šule qašti ${ }^{34}$

This brief imperative statement shows the enemy king in a last desperate, ridiculous, and pathetic attempt at command. His words have no power: both he and his son are next seen in the process of losing their heads.

To the side of the central drama of Teumman's beheading, we are provided with a contrast to this foolish and clearly vain continued resistance. A relative of Teumman, Urtak is shown in the midst of the Til-Tuba battle sequence, lying

34 All epigraphs are implicitly in the same first-person narrative voice of the king as other royal inscriptions, although this is only sometimes explicit. 
prone, raised up on one elbow. With this hand he gestures across his throat, while he extends the other hand towards an Assyrian soldier who faces him. Between them the epigraph reads (RINAP 5/1 28):

Urtak, in-law of Teumman, who was wounded by an [arrow] but had not yet given up his life, called out to an Assyrian to cut off his own head, saying 'Come, cut off my head, bring it before the king your lord, get a good name (for yourself)'.

\section{Urtaku hatanu Teumman \\ ša ina ‘ușșī muhhușu lā iqtû napšāti \\ ana ‘nakās` qaqqad ramānišu mār māt aššur \\ išassima umma alka qaqqadī nakis \\ pān šarri belīka išima leqi šum damiqtim}

This is a striking statement of surrender, an enemy asking for his own death and understanding the role that his severed head will play in post-battle celebrations. ${ }^{35}$ The words and gestures of this character Urtak show him dying in acknowledgment of Assyrian values, and understanding the bloody tribute due to an Assyrian king from an enemy who has disobeyed him.

The incident is dramatic and memorable, and serves as a commentary on the more central decapitation of Teumman, whose head is also borne by a common soldier to Ashurbanipal, as Urtak suggests should happen to him. This speech is probably a literary invention and not intended as a quotation from a previous source. Urtak is more like the unnamed enemies of Nineveh A who offer up their proverbial despair in acknowledgement of Esarhaddon's might: an enemy serving as a literary testament to Assyrian power. An Assyrian scribe and an Assyrian artist force this testimony through literary devices, just as the reliefs show us Assyrian soldiers forcing Umbadarâ and Nabû-damiq to speak words that will seal their fate. These instances of quotation, and references to enemy speech, in the Southwest Palace reliefs and accompanying epigraphs together show us the continuity between the literary act of forcing an enemy, as a character in image or text, to praise Assyria, and forcing enemies in real victory processions and treaty ceremonies to praise Assyria or to speak words that will testify to their need to be punished. The texts and images that survive to us are one part of a sequence of acts of performance and recording of speech related to each other.

35 On the significance of severed heads as objects that bring honour to the soldier who takes them, see Radner 2011: 39-43, 47-49. 


\section{Conclusion}

From the examples and discussion above several conclusions can be drawn. First we can conclude that most instances of direct speech in these late Assyrian royal texts are 'quotations' in a true sense: they are understood by their authors as an attempt to preserve speech that existed first somewhere else. For a quotation to be true, accurate, or powerful, we need to understand the process of 'quoting' broadly. Quotations of gods' answers to oracular queries, delivered through marks on animal livers, then recorded by scholars on clay tablets and perhaps subject to narrative expansion, are considered 'speech', which has been quoted faithfully and directly. Faithful and direct quotation of speech can be preserved through various other transformations, such that the prism inscriptions can 'quote' hostile words of Teumman that were relayed through a letter, recorded and probably read out by a messenger. The words of Ishtar, received from a dream interpreter, applying his skill to unclear dream images, are also presented as faithful quotation. Words are similarly powerful whether spoken, written in code understood only by diviners, or written in cuneiform (the latter two being similar and related systems).

The importance of quotation of this type in the Esarhaddon and Ashurbanipal texts examined here is unusual within the royal inscription genre. But the literary mechanisms of 'quoting' speech were already there for the taking in numerous other genres of cuneiform literature. Most obviously, letters are framed by narrative conventions in which the text quotes speech (which implicitly should also be performed when read out). Letters also are often densely packed with nested quotations - of previous correspondence, of imagined future responses, of overheard words or messages relayed by a party other than the sender. Treaties and ritual texts formulate direct speech as it should be spoken by participants. Unfamiliar as direct speech is within the genre of Assyrian royal inscriptions, the conventions for recording it, and the conception of its importance, were certainly there.

Enemies' words are particularly powerful, as serious threats and yet also as potential tools to reify Assyrian power structures. The crime of enemy speech is taken very seriously. This is true in the various Ashurbanipal examples in which blasphemous or insulting speech is centred as a punishable offense. The threatening nature of hostile speech was also apparently taken seriously outside of these literary narratives, as the emphasis on criminal speech acts in Esarhaddon's Succession Treaty indicates. What enemies say is potentially as dangerous as what arms they might take up. For this reason, we find enemy speech equated with other hostile acts, like military incursions, the mustering of troops, or plots 
against the king's life, and punished alongside it. In Ashurbanipal's texts, in the same literary dynamic Hurowitz (2008: 110-120) identified in Sargon II's account of Ursa of Urartu's 'shutting up', speech and military aggression are paired: as similar crimes, deserving of similar punishment.

Yet we have also seen that enemy words, with their unique potency, can be turned for ill or for good. As such, in the texts examined here, enemy direct speech fulfills one of two basic functions: to document enemy crimes, with hostile speech being a very severe crime, or to force defeated enemies to testify to Assyrian might and legitimacy. It is for this testimonial purpose that Ashurbanipal's Southwest Palace epigraphs show us Urtak surrendering and proclaiming Assyrian rights over his body and his life, and that Esarhaddon imagines unnamed enemies who despair of escaping his power. Creating images and narratives in which enemies proclaim their surrender and despair is part of a real humiliation of defeated enemies, apparently practiced during victory processions as well as in narrative, and the consolidation of Assyrian power over them. Thus Esarhaddon's highly literary Nineveh A can put its climactic statement about the power and legitimacy of Esarhaddon as Assyrian king in the mouth of proverbial, proverb quoting enemies who explain that he is the sun (/sun god), and they a fleeing fox before him. At the same time that they are brought low, these humiliated enemies assume a central position in Assyrian legitimation discourses: determining who is a king by who is able to reduce them to despairing capitulation.

\section{References}

Alster, Bendt. 1996. Literary Aspects of Sumerian and Akkadian Proverbs. in Mesopotamian Poetic Language Sumerian and Akkadian: Proceedings of the Groningen Group for the Study of Mesopotamian Literature, eds. M. E. Vogelzang, and H. L. J. Vanstiphout. Groningen: Styx Publications.

Bahrani, Zainab. 2008. Rituals of War: The Body and Violence in Mesopotamia. New York: MIT Press.

Barnett, Richard D. 1976. Sculptures from the North Palace of Ashurbanipal at Nineveh (668-627 $B C)$. London: British Museum Publications.

Barnett, Richard D., Erika Bleibtreu, and Geoffrey Turner. 1998. Sculptures from the Southwest Palace of Sennacherib at Nineveh. London: British Museum Press.

Baruchi-Unna, Amitai. 2013. Genres Meet: Assurbanipal's Prayer in the Inscription L4 and the Bilingual Communal Lamentations. Pp. 611-23 in Time and History in the Ancient Near East Proceedings of the 56th Rencontre Assyriologique Internationale, Barcelona, July 26-30, 2010, ed. Lluis Feliu. Winona Lake: Eisenbrauns. 
Baruchi-Unna, Amitai. 2017. Reporting the Content of Divine Positive Response (annu kēnu) in Assyrian Royal Inscriptions. Pp. 341-70 in "Now It Happened in Those Days" Studies in Biblical, Assyrian, and Other Ancient Near Eastern Historiography Presented to Mordechai Cogan on His 75th Birthday, eds. Amitai Baruchi-Unna, Tova Forti, Shmuel Ahituv, Israel Eph'al, and Jeffrey H. Tigay. Winona Lake: Eisenbrauns.

Borger, Rykle. 1967. Die Inschriften Asarhaddons, Königs von Assyrien. Osnabrück: BiblioVerlag.

Borger, Rykle. 1996. Beiträge zum Inschriftenwerk Assurbanipals: die Prismenklassen A, B, $C=K, D, E, F, G, H$, J und $T$ sowie andere Inschriften. Wiesbaden: Harrassowitz Verlag.

Campbell Thompson, Reginald. 1931. The Prisms of Esarhaddon and Ashurbanipal Found at Nineveh 1927-8. London: British Museum Press.

Collins, Paul. 2006. The Development of the Individual Enemy in Assyrian Art. Source: Notes in the History of Art 25/3: 1-8.

Fales, Frederick Mario. 2012. After Ta'yinat: The New Status of Esarhaddon's adê for Assyrian Political History. Revue d'assyriologie et d'archéologie orientale 106/1: 133-58.

Feldman, Marian H. 2014. Communities of Style: Portable Luxury Arts, Identity, and Collective Memory in the Iron Age Levant. Chicago: University of Chicago Press.

Feldman, Marian H. 1998. Humor in Assyrischen Konigsinschriften. Pp. 147-62 in Intellectual Life of the Ancient Near East, ed. Jiří Prosecký. Prague: Oriental Institute.

Feldman, Marian H. 2010. Hochverrat in Assur. Pp. 89-139 in Assur-Forschungen: Arbeiten Aus Der Forschungsstelle "Edition Literarischer Keilschriftexte Aus Assur" Der Heidelberger Akademie Der Wissenschaften, eds. Stefan Maul, and Nils P. Heeßel. Wiesbaden: Harrassowitz Verlag.

Feldman, Marian H. 2013. Rising Suns and Falling Stars: Assyrian Kings and the Cosmos. Pp. 97-120 in Experiencing Power, Generating Authority: Cosmos, Politics, and the Ideology of Kingship in Ancient Egypt and Mesopotamia, eds. Jane A. Hill, Philip Jones, and Antonio J. Morales. Philadelphia: University of Pennsylvania Press.

Frahm, Eckart. 1997. Einleitung in die Sanherib-Inschriften. Horn, Austria: Institut für Orientalistik der Universität.

Geltner, G. 2014. Flogging Others: Corporal Punishment and Cultural Identity from Antiquity to the Present. Amsterdam: Amsterdam University Press.

Genette, Gérard. 1983. Narrative Discourse: An Essay in Method. Ithaca, New York: Cornell University Press.

Gerardi, Pamela. 1987. Assurbanipal's Elamite Campaigns: A Literary and Political Study. Philadelphia: University of Pennsylvania.

Gerardi, Pamela. 1988. Epigraphs and Assyrian Palace Reliefs: The Development of the Epigraphic Text. Journal of Cuneiform Studies 40/1: 1-35.

Gerardi, Pamela. 1989. Thus, He Spoke: Direct Speech in Esarhaddon's Royal Inscriptions. Zeitschrift für Assyriologie 79: 245-60.

Gilibert, Alessandra. 2018. Teumman's Last Supper. Pp. 289-308 in Übergangszeiten: Altorientalische Studien für Reinhard Dittmann Anlässlich seines 65. Geburtstags, eds. Kai Kaniuth, Daniel Lau, and Dirk Wicke. Münster: Zaphon.

Grayson, A. K., and J. R. Novotny. 2014. The Royal Inscriptions of Sennacherib, King of Assyria (704-681 BC). Royal Inscriptions of the Neo-Assyrian Period 3/2. Winona Lake, Indiana: Eisenbrauns.

Grayson, A. Kirk. 1980a. Assyria and Babylonia. Orientalia 49/2: 140-94. 
Grayson, A. Kirk. 1980b. The Chronology of the Reign of Ashurbanipal. Zeitschrift für Assyriologie und Vorderasiatische Archäologie 70/2: 227-45.

Grayson, A. Kirk. 1987. Akkadian Treaties of the Seventh Century BC. Journal of Cuneiform Studies 39/2: 127-60.

Hurowitz, Victor Avigdor. 2008. 'Shutting up' the Enemy-literary Gleanings from Sargon's Eighth Campaign. Pp. 104-20 in Treasures on Camels' Humps-Historical and Literary Studies from the Ancient Near East Presented to Israel Eph'al, eds. Mordechai Cogan, and D. Kahn. Jerusalem: Hebrew University Magnes.

Hurowitz, Victor Avigdor. 2009. A Monument to Imperial Control: Literary Observations on the Thompson Prism of Esarhaddon (Nineveh A). Pp. 121-65 in Homeland and Exile: Biblical and Ancient near Eastern Studies in Honour of Bustenay Oded, eds. Gershon Galil, Mark Geller, and Alan Millard. Leiden: Brill.

James, Henry. 1888. The Art of Fiction. Pp. 375-408 in Partial Portraits, ed. Henry James. London: Macmillan.

Knapp, Andrew. 2016. The Sitz im Leben of Esarhaddon's Apology. Journal of Cuneiform Studies 68: 181-95.

Lambert, Wilfred G. 1960. Babylonian Wisdom Literature. Winona Lake: Eisenbrauns.

Lauinger, Jacob. 2012. Esarhaddon's Succession Treaty at Tell Tayinat: Text and Commentary. Journal of Cuneiform Studies 64: 87-123.

Lauinger, Jacob. 2015. Neo-Assyrian Scribes, Esarhaddon's Succession Treaty, and the Dynamics of Textual Mass Production. Pp. 285-314 in Texts and Contexts: The Circulation and Transmission of Cuneiform Texts in Social Space, eds. Paul Delnero, and Jacob Lauinger. Berlin: De Gruyter.

Leichty, Erle. 2011. The Royal Inscriptions of Esarhaddon, King of Assyria (680-669 BC). Royal Inscriptions of the Neo-Assyrian Period 4. Winona Lake, Ind: Eisenbrauns.

Livingstone, A. 1989. Court Poetry and Literary Miscellanea. State Archives of Assyria 3. Helsinki: Helsinki University Press.

Machinist, Peter. 1993. Assyrians on Assyria in the First Millennium BC. Pp. 77-104 in Anfänge politischen Denkens in der Antike Die nahöstlichen Kulturen und die Griechen, eds. Kurt Raaflaub, and Elisabeth Müller-Luckner. Munich: R. Oldenbourg Verlag.

May, Natalie Naomi. 2014. 'In Order to Make Him Completely Dead': Annihilation of the Power of Images in Mesopotamia. In La famille dans le Proche-Orient ancien: réalités, symbolismes, et images : Proceedings of the 55th Rencontre Assyriologique Internationale at Paris, 6-9 July 2009, edited by Lionel Marti, 701-26. Winona Lake: Eisenbrauns.

Novotny, Jamie. 2003. Zahalû-Metal for Marduk's Paramahu and the Date of Assurbanipal's E-Prisms. Orientalia: Commentarii Periodici de Rebus Orientis Antiqui.

Novotny, Jamie, and Joshua Jeffers. 2018. The Royal Inscriptions of Ashurbanipal. Royal Inscriptions of the Neo-Assyrian Period 5/1. Eisenbrauns: University Park, Pennsylvania.

Oppenheim, A. Leo. 1956. The Interpretation of Dreams in the Ancient near East. With a Translation of an Assyrian Dream-Book. Transactions of the American Philosophical Society 46/3: 179-373.

Parpola, Simo. 1980. The Murderer of Sennacherib. Pp. 171-82 in Death in Mesopotamia: Papers Read at the XXVIe Rencontre Assyriologique Internationale, ed. Bendt Alster. Copenhagen: Akademisk forlag.

Parpola, Simo. 1983. Letters from Assyrian Scholars to the Kings Esarhaddon and Assurbanipal Part II: Commentary and Appendices. Kevelaer: Butzon \& Bercker. 
Parpola, Simo. 1987. Neo-Assyrian Treaties from the Royal Archives of Nineveh. Journal of Cuneiform Studies 39/2: 161-89.

Parpola, Simo. 2018. The Correspondence of Assurbanipal: Part l, Letters from Assyria, Babylonia and Vassal States. State Archives of Assyria 21. Helsinki: The Neo-Assyrian Text Corpus Project.

Parpola, Simo, and Kazuko Watanabe. 1988. Neo-Assyrian Treaties and Loyalty Oaths. State Archives of Assyria 2. Helsinki: Helsinki University Press.

Piepkorn, Arthur Carl. 1933. Historical Prism Inscriptions of Ashurbanipal I. Assyriological Studies; No. 5. Chicago: University of Chicago Press.

Pongratz-Leisten, Beate. 2015. Religion and Ideology in Assyria. Berlin: De Gruyter.

Radner, Karen. 2007. The Trials of Esarhaddon: The Conspiracy of 670 BC. Pp. 165-84 Isimu 6. in Assur und Sein Umland, eds. P. A. Miglus, and J. M. Córdoba. Madrid: Universidad Autónoma de Madrid.

Radner, Karen. 2011. Fame and Prizes: Competition and War in the Neo-Assyrian Empire. Pp. 37-57 in Competition in the Ancient World, eds. Nick Fisher, and Hans van Wees. Swansea: Classical Press of Wales.

Radner, Karen. 2015. Royal Pen Pals: The Kings of Assyria in Correspondence with Officials, Clients, and Total Strangers (8th and 7th Centuries BC). Pp. 61-72 in Official Epistolography and the Language(s) of Power, eds. Stefan Prochazka, Lucian Reinfandt, and Sven Tost. Vienna, Austria: Verlag der Österreichischen Akademie der Wissenschaften.

Reade, Julian E. 2005. Religious Ritual in Assyrian Sculpture. Pp. 7-61 in Ritual and Politics in Ancient Mesopotamia, ed. Barbara Nevling Porter. New Haven: American Oriental Society.

Rimmon-Kenan, Shlomith. 2002. Narrative Fiction: Contemporary Poetics. 2nd ed. London: Routledge.

Robson, Eleanor. 2011. Empirical Scholarship in the Neo-Assyrian Court. Pp. 603-30 in Die Empirische Dimension Altorientalischer Forschungen/The Empirical Dimension of Ancient Near Eastern Studies, eds. Gebhard Selz, and Klaus Wagensonner. Münster: LIT Verlag.

Russell, John Malcolm. 1999. The Writing on the Wall: Studies in the Architectural Context of Late Assyrian Palace Inscriptions. Winona Lake: Eisenbrauns.

Starr, Ivan. 1990. Queries to the Sungod: Divination and Politics in Sargonid Assyria. State Archives of Assyria 4. Helsinki, Finland: Helsinki University Press.

Tadmor, Hayim. 1983. Autobiographical Apology in the Royal Assyrian Literature. Pp. 36-57 in History, Historiography, and Interpretation: Studies in Biblical and Cuneiform Literatures, eds. Hayim Tadmor, and Moshe Weinfeld. Leiden, Jerusalem: Brill, The Hebrew University.

Tadmor, Hayim. 2004. An Assyrian Victory Chant and Related Matters. Pp. 269-76 in From the Upper Sea to the Lower Sea: Studies on the History of Assyria and Babylonia in Honour of A.K. Grayson, eds. Grant Frame, and L. S. Wilding. Leiden: Nederlands Instituut voor het Nabije Oosten.

Talon, Philippe. 2005. Cases of Deviation in Neo-Assyrian Annals and Foundation Documents. Pp. 99-114 in Ritual and Politics in Ancient Mesopotamia, ed. Barbara Nevling Porter. New Haven: American Oriental Society.

Waters, Matthew W. 1999. Te'umman in the Neo-Assyrian Correspondence. Journal of the American Oriental Society 119/3: 473-77.

Waters, Matthew W. 2002. A Letter from Ashurbanipal to the Elders of Elam (BM 132980). Journal of Cuneiform Studies 54: 79-86. 
Waters, Matthew W. 2013. Elam, Assyria, and Babylonia in the Early First Millennium BC. Pp. 478-92 in The Oxford Handbook of Ancient Iran, ed. D. T. Potts. Oxford: Oxford University Press.

Weidner, Ernst F. 1932. Assyrische Beschreibungen der Kriegs-Reliefs Assurbânaplis. Archiv für Orientforschung 8: 175-203.

Weissert, Elnathan. 1998. Aššūr-bāni-apli. Pp. 159-63 in The Prosopography Neo-Assyrian Empire, 1/1: A, Vol. I. PNA, I, ed. Karen Radner. Winona Lake, Indiana: Eisenbrauns.

Wiseman, D. J. 1958. The Vassal-Treaties of Esarhaddon. Iraq 20/1: 1-99.

Wiseman, D. J. 1974. Murder in Mesopotamia. Iraq 36/1/2: 249-60.

Zgoll, Annette. 2014. Dreams as Gods and Gods in Dreams: Dream-Realities in Ancient Mesopotamia from the 3rd to the 1st Millennium BC. Pp. 299-314 in He Has Opened Nisaba's House of Learning: Studies in Honor of Åke Waldemar Sjöberg on the Occasion of His 89th Birthday on August 1st 2013, ed. Leonhard Sassmannshausen. Leiden: Brill. 
